\title{
Relationships between Plasma Levels of Thyroxine and Its Binding Proteins in the Chick Embryo
}

\author{
Yasuhiko Nishiguchi ${ }^{1)}$ and Sadao Hoshino \\ Faculty of Bioresources, Mie University. Tsu 514
}

\begin{abstract}
Plasma levels of thyroxine (T4), total proteins, albumin and transthyretin (T4binding prealbumin) were determined in chick embryos at 19 days of incubation. There were significant sex differences $(\mathrm{P}<0.05)$ in plasma levels of $\mathrm{T} 4$ and total proteins. A highly significant positive correlation between plasma levels of $\mathrm{T} 4$ and albumin $(\mathrm{r}=0.55$, $\mathrm{P}<0.001, \mathrm{n}=42$ ) was found; this suggests that plasma albumin level may be a useful parameter to evaluate thyroid function in the chick embryo. Moreover it was confirmed that both albumin and transthyretin were major T4-binding proteins in chick embryos as well as in growing chickens.
\end{abstract}

(Jpn. Poult. Sci., 30:310-315, 1993)

Key words : thyroxine, albumin, thyroxine-binding proteins, chick embryo

\section{Introduction}

In birds, plasma thyroid hormones are bound principally to albumin and transthyretin (thyroxine-binding prealbumin) and, to a minor extent, to lipoproteins and globulins (Davison et al., 1978; Mitchell and Stiles, 1985 ; Cookson et al., 1988). The association of thyroid hormones to their binding proteins may retard clearance rates of circulating hormones and support continuous synthesis and release of the hormones by decreasing plasma concentrations of free hormone that is regarded as important in the negative feedback mechanism (LARSEN, 1982). However, we lack definite information on the binding proteins of thyroid hormones in the chick embryo. Moreover, we have only scanty information about relationships between the levels of circulating thyroid hormones and their binding proteins in chikens.

Experiments reported in this communiation show the existence of thyroxine (T4)binding proteins and a positive correlation between plasma T4 and albumin levels in the chick embryo.

\section{Materials and Methods}

\section{Animals}

Fertilized eggs (Babcock B-300) were incubated in a force-draft laboratory incubator at $37.8^{\circ} \mathrm{C}$ with a constant relative humidity of $60 \%$ and turned once every $4 \mathrm{~h}$. After incubation for 19 days, blood samples were obtained by heart puncture into

Received Dec. 21, 1992

${ }^{1)}$ Present address : National Institute of Animal Industry, Norindanchi P.O. Box 5, Tsukuba 305 
heparinized tubes. Plasma was separated by centrifugation $(2,000 \times \mathrm{g}, 20 \mathrm{~min})$ and stored at $-20^{\circ} \mathrm{C}$ until assayed.

\section{Determination of plasma albumin and transthyretin concentrations}

Serum albumin and transthyretin were purified from broiler sera obtained from a local processing company as described by Schwert (1957) and ABE et al. (1975), respectively. The purified proteins, both of which gave a single band on disc polyacrylamide gel electrophoresis (PAGE) (DAvis, 1964), were used as antigens to raise antisera in rabbits in the usual manner. The antisera raised were specific to the antigens and showed no crossreactivity with the other plasma proteins and ovoalbumin in the immunoelectrophoresis (GrabAR and Williams, 1955). Using these antisera, plasma albumin and transthyretin concentrations were determined by a single-radial immunodiffusion method (MANcini et al., 1965) as follows. Plasma $(2.5 \mu l)$ or standard solutions (albumin, $0-20 \mathrm{mg} / \mathrm{ml}$; transthyretin, $0-2 \mathrm{mg} / \mathrm{ml})(2.5 \mu l$ each) were dispensed into holes $(2 \mathrm{~mm}$ in diameter) on $1 \%(\mathrm{w} / \mathrm{v})$ agar plate containing $1 \%(\mathrm{v} /$ v) antisurum. The plates were incubated for $24 \mathrm{~h}$ at $30^{\circ} \mathrm{C}$ under humid condition.

Diameters of the resultant precipitate rings were measured and then protein concentrations were determined from the calibration lines made with the standard solutions of albumin and transthyretin. The intraassay variaitions (c.v.) of albumin and transthyretin were $4.3 \%(n=5)$ and $5.9 \%(n=5)$, respectively. The assays were carried out in duplicate at one time to expel interassay variations. The calibration lines for albumin and transthyretin were $\mathrm{Y}=0.4762+0.0968 \mathrm{X}(\mathrm{r}=0.97, \mathrm{P}<0.001)$ and $\mathrm{Y}=0.2104+$ $0.0052 \mathrm{X}(\mathrm{r}=0.99, \mathrm{P}<0.001)$ respectively, where $\mathrm{Y}$ is protein concentration $(\mathrm{mg} / \mathrm{ml})$ and $\mathrm{X}$ is (diameter of the rings in $\mathrm{cm})^{2}$.

Concentrations of total plasma proteins were measured by the method of Low Y et al. (1951). Plasma T4 levels were determined by a radioimmunoassay described previously (Hoshino et al., 1993).

\section{Detection of plasma T4-binding proteins}

Plasma from 6 embryos ( 3 males and 3 females) was pooled. Plasma from 6 -week -old chickens ( 2 males) was also pooled. The pooled plasma $(50 \mu l)$ of each group was incubated with $1 \mathrm{ng}(200,000 \mathrm{cpm}$, dissolved in $10 \mu \mathrm{l}$ of ethanol: water $=3: 1$ solution $)$ of ${ }^{125} \mathrm{I}-\mathrm{T} 4$ (Amersham) in a plastic tube for $4 \mathrm{~h}$ at room temperature, and then $1 \mathrm{~m} l$ of $1 \%$ $(\mathrm{w} / \mathrm{v})$ sucrose solution containing $5 \%(\mathrm{w} / \mathrm{v})$ activated charcoal (Norit $\mathrm{A})$ was added to the tube to remove free ${ }^{125} \mathrm{I}-\mathrm{T} 4$. Fifty $\mu l$ of this mixture was applied to the disc-PAGE of DAvis (1964) and the electrophoresis was run vertically with a constant current of 2 $\mathrm{mA} / \mathrm{gel}$. After completion of electrophoresis, gels were cut into $1.5 \mathrm{~mm}$ segments and their radioactivities were measured with an automatic gamma counter (ARC-600. Aloka). The pooled plasma of embryo $(5 \mu l)$ and of chick $(2 \mu l)$ were run at the same time and stained with Coomassie brilliant blue G-250 to detect proteins.

\section{Statistics}

Statistical analyses of data were made using Student's $t$-test or Cochran-Cox test.

\section{Results}

Plasma levels of T4 and blood proteins in the embryos at 19 days of incubation are 
Table 1. Plasma levels of thyroxione, total proteins, albumin and transthyretin (thyroxine-binding prealbumin) in chick embryos at 19 days of incubation (mean $\pm \mathrm{SE}$ )

\begin{tabular}{lcccc}
\hline \hline & $\begin{array}{c}\text { Thyroxine } \\
(\mathrm{ng} / \mathrm{m} l)\end{array}$ & $\begin{array}{c}\text { Total proteins } \\
(\mathrm{mg} / \mathrm{m} l)\end{array}$ & $\begin{array}{c}\text { Albumin } \\
(\mathrm{mg} / \mathrm{m} l)\end{array}$ & $\begin{array}{c}\text { Transthyretin } \\
(\mu \mathrm{g} / \mathrm{m} l)\end{array}$ \\
\cline { 2 - 6 } Female $(\mathrm{n}=18)$ & $14.12 \pm 1.22$ & $23.45 \pm 1.69$ & $6.93 \pm 0.60$ & $72.30 \pm 4.53$ \\
Male $\quad(\mathrm{n}=24)$ & $10.57 \pm 0.96^{*}$ & $17.83 \pm 1.74^{*}$ & $6.12 \pm 0.33$ & $72.82 \pm 5.08$ \\
\hline
\end{tabular}

${ }^{*} \mathrm{P}<0.05$ vs female

shown in Table 1. Both plasma T4 and total protein levels were significantly higher in female embryos than in male embryos. However, there were no significant sex differences in plasma levels of albumin and transthyretin. When data were correlated by linear reqression, a significant positive correlation was found between plasma levels of $\mathrm{T} 4$ and albumin $(\mathrm{r}=0.55$ for pooled data, $\mathrm{P}<0.001, \mathrm{n}=42 ; \mathrm{r}=0.58$ for females, $\mathrm{P}<0.05$, $\mathrm{n}=18 ; \mathrm{r}=0.46$ for males, $\mathrm{P}<0.05, \mathrm{n}=24$ ). However, neither total protein nor transthyretin levels were significantly correlated with plasma T4 levels.

Patterns of ${ }^{125}$ I-T4-binding to plasma proteins, together with electrophoretic profiles of proteins, are shown in Figs. 1 and 2. The radioactivities were mainly detected in albumin and transthyretin, and to some extent in the other protein fractions. The T4-binding pattern of 6 -week-old chicken plasma was similar to that of embryos, though the amounts of binding to proteins, especially to albumin, tended to decrease in the growing chickens.

\section{Discussion}

The present study clearly showed a significant positive correlation between plasma levels of T4 and albumin, which appears to be a major T4-binding protein in chick embryos as well as in chickens after hatch, suggesting possible involvement of albumin in the thyroidal function of chick embryos. For instance, it is possible that the thyrotropic activity of estrediol $\left(\mathrm{E}_{2}\right)$ observed in the previous experiments (HosHino et al., 1987, 1990 ; Huу вRECH's et al., 1990) could have been sustained by an increase in albumin concentration. Estrogens are known to increase the plasma vitellogenin concentrations in cockerels (CLEGg et al., 1951) and quails (Gibins and Robinson, 1982), and vitellogenin appears to bind thyroid hormones (Mitchell and Stiles, 1985). However, because of small quantities of T4-binding to vitellogenin (DAvison et al., 1978 ; Mitchell and Stiles, 1985; Cookson et al., 1988), it is unlikely that an increase in vitellogenin is responsible for the enhanced thyrotropic activity in the $\mathrm{E}_{2}$-treated chick embryo. However, these possibilities should be examined in further experiments.

In the present study $\mathrm{T} 4$ levels in female embryos were significantly higher than in males. Although causes underlying this sex difference are unknown at present, it is possible that the sex difference is due partly to the significantly higher level of total plasma proteins including albumin in female embryos (Table 1).

The electrophoretic separation of T4-binding proteins in the present study was carried out at $\mathrm{pH} 8.6$, which is somewhat above the physiological range of chicken 


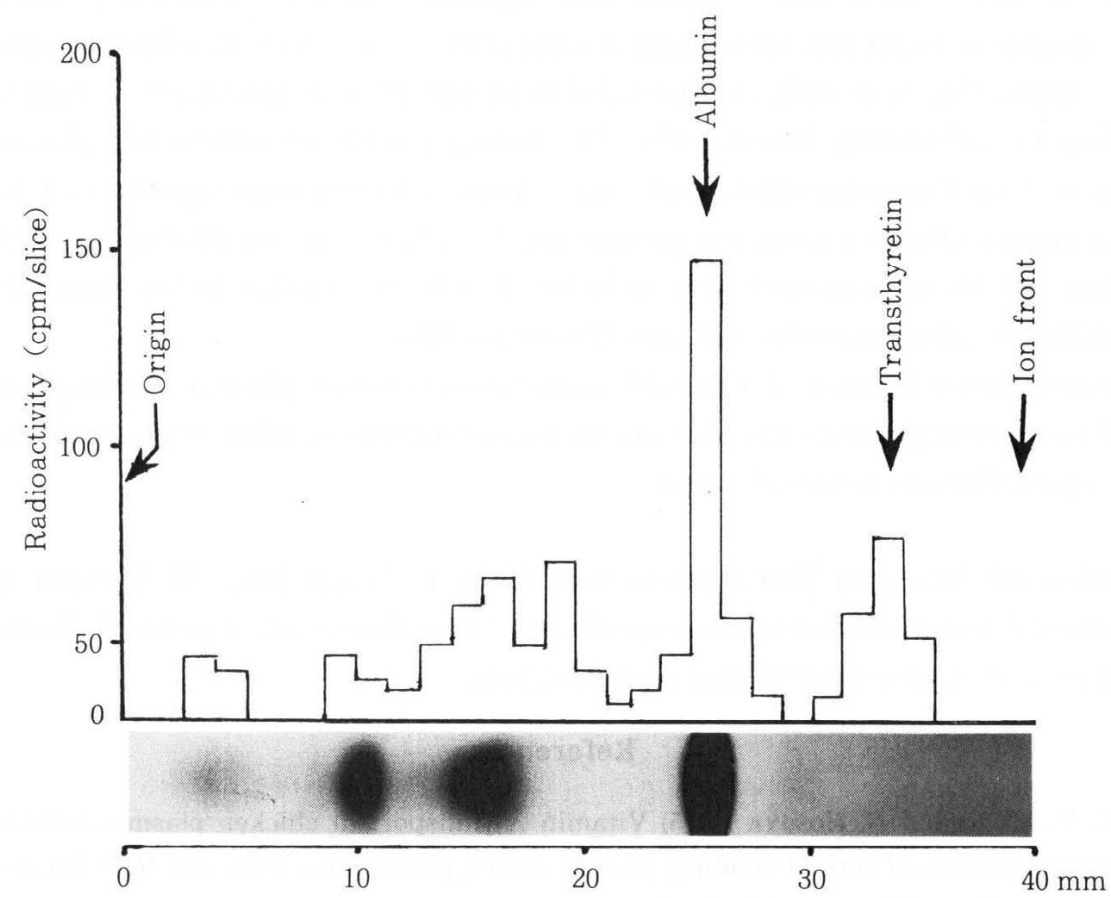

Fig. 1. Distribution of ${ }^{125}$ I-thyroxine and serum proteins stained with Coomassie brilliant blue G-250 after electrophoresis in 19-day-old chick embryos.

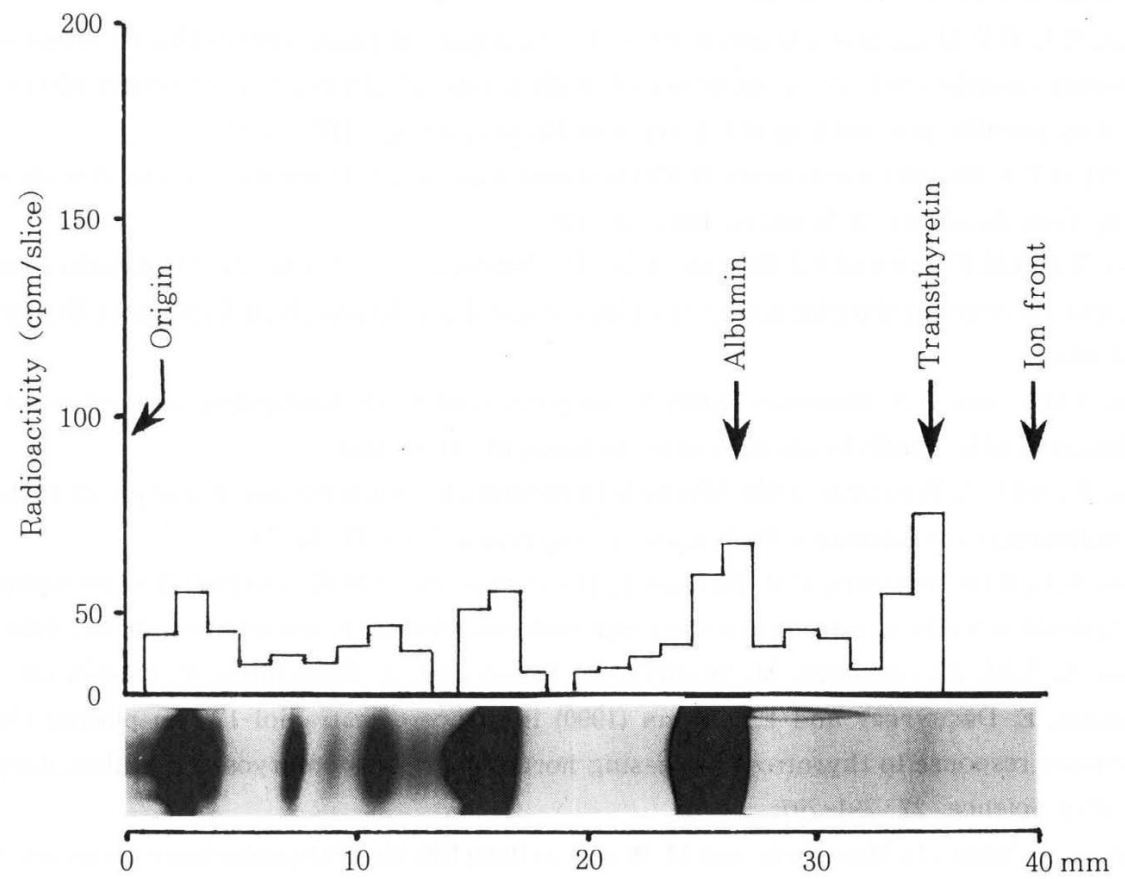

Fig. 2. Distribution of ${ }^{125} \mathrm{I}$-thyroxine and serum proteins stained with Coomassie brilliant blue G-250 after electrophoresis in 6-week-old chickens. 
blood. However, there was no substantial difference in electrophoretic profiles from those separated under the physiological pH (pH 7.4) (DAvison et al., 1978; Mitchell and Stiles, 1985); this may indicate the validity of the present procedure to estimate T4 situation in circulating blood. The T4-binding profile of embryonic plasma was similar to that of growing chicken plasma. Although there is no report on T4-binding proteins in the chick embryo, the present result indcates the establishment of thyroid function and its transporting system before hatch, in addition to the maturation of hypothalamo-adenohypophyseal axis (Tномmes, 1987).

In conclusion, because of a possible correlation between plasma T4 and albumin, it would be advantageous to measure albumin concentrations when thyrotropic activity in the chick embryo is investigated.

Acknowledgements-The authors would like to thank Drs. M. Wakita and Y. Kobayashi for their advice on the experiment. Our thanks are also due R. Yamamoto and D. Morishita for their skilled technical help.

\section{References}

AвE, T., Y. Muto and N. Hosoya (1975) Vitamin A transport in chicken plasma: isolation and characterization of retinol-binding protein. (RBP), prealbumin (PA), and RBP-PA complex. Journal of Lipid Research, $16: 200-210$.

Clegg, R.E., P.E. Sanford, R.E. Hein, A.C. Andrews, J.S. Hughes and C.D. Mueller (1951) Electrophoretic comparison of the serum proteins of normal and diethylstilbestrol treated cockerels. Science, $114:$ 437-438.

Cookson, E.J., M.R. Hall and J. Glover (1988) The transport of plasma thyroxine in White storks (Ciconia ciconia) and the association of high levels of plasma transthyretin (thyroxinebinding prealbumin) with moult. Journal of Endocrinology, 117: 75-84.

DAvis, B.J. (1964) Disc electrophoresis. II. Method and application to serum proteins. Annals of the New York Academy of Sciences. 121 : 404-427.

Davison, T.F., I.H. FLACK and E.J. Butler (1978) The binding of thyroxine and tri-iodothyronine to plasma proteins in the chicken at the physiological pH. Research in Veterinary Science 25 : $280-283$.

Gibbins, A.M.V. and G.A. Robinson (1982) A comparison of diethylstilbestrol- and estradiol-17 $\beta$ induced vitellogenesis in quail. Poultry Science, 61 : 1188-1193.

Grabar, P. and C.A. Williams (1955) Methode immmunoélectrophoretique d'analyse de mélanges de substances antigéniques. Biohimica et Biophysica Acta, 17:67-74.

Hoshino, S., L.M Huybrechts, V.M. Darras, E. Decuypere and E.R. Kühn (1987) Thy rotrophic and peripheral activity of estradiol in the chick embryo. Medical Science Research. 15 : 1409-1410.

Hoshino, S., L.M. Huybrechts, M. Wakita, Y. Kobayashi, I. Yamamoto, Y. Nishiguchi, V.M. Darras, E. Decuypere and E.R. KÜHN (1990) Influence of estradiol-17 $\beta$ on plasma thyroid hormone response to thyrotropin releasing hormone in chick embryos and pullets. Japanese Poultry Science, 27 : 291-297.

Hoshino, S., T. Nagai, D. Morishita and M. Wakita (1993) Effects of thyoidectomy on serum levels of growth hormone, insulin-like growth factor (IGF)- 1 and IGF-binding activity in dwarf and normal cockerels. Japanese Poultry Science, 30 : 203-206.

Huybrechts, L.M., S. Hoshino, M. Wakita, Y. Kobayashi, V.M. Darras, E. Decuypere and E.R. 
KÜHN (1990) Thyrotropic activity of estradiol in the chick embryo develops without increase in pituitary thyrotropin releasing hormone binding. Japanese Poultry Science, 27 : 318-323.

LARSEN, P.R. (1982) Thyorid-pitultary interaction; Feedback requlation of thyrotropin secretion by thyroid hormones. New England Journal of Medicine, 306 : 23-32.

Lowry. O.H., N.J. Rosebrough, A.L. Farr and R.J. Randall (1951) Protein measurement with Folin phenol reagent. Journal of Biological Chemistry, 193 : 265-275.

Mancini, G., A.O. Carbonara and J.F. Heremans (1965) Immunochemical quantitation of antigens by single radial immunodiffusion. Immunochemistry, $2: 235-254$.

Mitchell, M.A. and M.S. Stiles (1985) Some new observations on the binding of thyroxine and triiodothyronine to plasma proteins and lipoproteins in the domestic fowl. General and Comparative Endocrinology, $57:$ 309-319

Schwert, G.W. (1957) Recovery of native bovine serum albumin after precipitation with trichloroacetic acid and solution in organic solvents. Journal of American Chemical Society, 79 : 139-141.

Тноммеs, R.C. (1987) Ontogenesis of thyroid function and regulation in the developing chick embryo. Journal of Experimental Zoology, Supplement $1: 273-279$. 